\title{
Assessment of Lead Levels in Maternal Blood Samples by Graphite Furnace Atomic Absorption Spectrometry and Influence of Maternal Blood Lead on Newborns
}

\author{
"Bayram Yüksel ${ }^{a, b}$, Zeliha Kayaaltía $^{a}$ Dilek Kaya-Akyüzlüa, Deniz Tekin ${ }^{a}$, and Tulin Söylemezoglu ${ }^{a}$ \\ a Ankara University, Institute of Forensic Sciences, Dikimevi, 06590, Ankara, Turkey \\ b Turkish National Police, Ankara Police Forensic Laboratory, Gölbasi, 06830, Ankara, Turkey
}

\begin{abstract}
Since fetal exposure to lead begins at the 21 st week of pregnancy, the fetus is at high risk from maternal lead exposure. Although the placenta, an interface between the developing fetus and the mother, has mechanisms that restrict the entry of toxicants, it cannot protect the fetus from exposure to lead from the mother's blood. Even lowlevel lead poisoning causes neurodevelopmental toxicity in children including mild mental retardation, low intelligence quotients (IQ) and attention span, reading and learning disabilities, hyperactivity and behavioral problems. Also, lead exposure during pregnancy has been shown to increase the risk for abortions, premature births and prenatal deaths.

The objective of this study was to detect whether or not maternal blood lead has an effect on newborns. This study involved 95 healthy, non-smoking, nonanemic pregnant women who have lived in Ankara, Turkey, for
\end{abstract}

more than 3 years. Maternal blood samples were obtained from Ankara University, Gynecology Department of Faculty of Medicine, Dikimevi, Ankara, Turkey. Infant characteristics such as placental weight, birth weight, birth length and head circumference were recorded. Maternal blood lead levels were quantified using Varian AA240Z Graphite Furnace atomic absorption spectrometry (GFAAS), equipped with Zeeman background correction. The method showed linearity in the range of $0-100 \mu \mathrm{g} / \mathrm{L}$, with a detection and quantification limit equal to 0.34 $\mu \mathrm{g} / \mathrm{L}$ and $1.03 \mu \mathrm{g} / \mathrm{L}$ respectively. Maternal blood levels ranged between 12.27 and $433.22 \mu \mathrm{g} / \mathrm{L}$. The mean maternal blood lead levels were found as $41.80 \pm 33.97$ ppb. No statistically significant correlation was found between maternal blood lead and birth weight $(\mathrm{r}=-0.128, \mathrm{p}=0.216)$, birth length $(r=-0.081, p=0.434)$, head circumferences $(r=-0.106$, $\mathrm{p}=0.308)$ and placental weight $(\mathrm{r}=-0.021, \mathrm{p}=0.840)$.

\section{INTRODUCTION}

Studies due to biological screening in toxicological research are important for the asssessment of human health risk considering environmental pollution. Toxic metals, including lead $(\mathrm{Pb})$, are one of the serious groups of environmental contaminants (1). Lead is known to have no beneficial role to humans,

\footnotetext{
* Corresponding autbor.

E-mail: bayramyuksel83@gmail.com

Tel.: +903124629565

Fax: +903124629429
}

and exposure to lead occurs in several routes of administration such as oral, inhalation, and dermal (1). Hence, lead is transported bound to erythrocytes and accumulates in the bones with a half-life of around 30 years $(2,3)$. Lead compounds and inorganic $\mathrm{Pb}$ are classified as "Group 2A" and considered probably carcinogenic to humans according to the International Agency for Research on Cancer (IARC) in 2006 (4). Unlike acute exposure, lowlevel environmental exposure to lead is related to multiple sources such as petrol, paint, water pipes, household dust, street dirt, and soil (5). In addition to these, some other sources are lead smelting industries, cigarette smoke, fuels utilized for heating, battery recycling plants, and occupational exposure such as at aircraft and car paint manufacturing plants (6). Thus, assessment of the relative contribution from sources is complicated and high and differs between regions and population groups (5).

Exposure to $\mathrm{Pb}$ can last for a lifetime. At first, a fetus meets many chemicals in placental transfer throughout the intrauterine life in diverse degrees (1). The main adverse effects of $\mathrm{Pb}$ are on the renal, hematopoietic and neurological systems. Since neuro development starts in the neonatal period when the blood-brain barrier is still immature, the target populations in terms of adverse neuro developmental effects of $\mathrm{Pb}$ are most likely children, especially infants in the neonatal period and as fetus (7-9). The placenta is an interface between the developing fetus and the mother, which has mechanisms to restrict the entry of toxicants (10). However, it cannot protect the fetus from exposure to $\mathrm{Pb}$ originating in maternal blood (7). Therefore, even low level exposure that is not significant for the mother can result in fetotoxic effects $(10,11)$. Despite the fact that postnatal and childhood exposure to $\mathrm{Pb}$ can cause health effects at low concentrations, infants who have been exposed to $\mathrm{Pb}$ in the prenatal time period can suffer from developmental problems with regard to intelligence, information processing, memory, and verbal skills as well as 
growth and behavior. Since $\mathrm{Pb}$ is incorporated into the bone matrix where it is retained for decades (12), bone becomes the main source of $\mathrm{Pb}$ in the blood, especially if dietary $\mathrm{Pb}$ is low (13).

The main goal of this study was to develop and validate a sensitive method using graphite furnace atomic absorption spectrometry (GFAAS), equipped with a Zeeman effect background correction system, for the determination of $\mathrm{Pb}$ in maternal blood samples and to be used for routine toxicological applications. The method developed was applied to the analysis of maternal blood samples provided from mothers voluntarily. The samples were taken from them at the Ankara University, Gynecology Department of Faculty of Medicine in Dikimevi, Ankara, Turkey. In addition, infant characteristics such as placental weight, birth weight, birth body length and head circumference were recorded in order to detect whether or not the maternal blood $\mathrm{Pb}$ level has an effect on newborns.

\section{EXPERIMENTAL}

\section{Instrumentation}

The $\mathrm{Pb}$ measurements were performed using a Varian AA240Z atomic absorption spectrometer (Varian, Inc., Victoria, Australia), equipped with a Zeeman background correction (BC) system. A boosted discharge hollow cathode lamp (Agilent Technologies, Inc., Australia) was used as the excitation source for lead. The instrumental operating parameters of the GFAAS system are listed Table I.

\section{Standard Solutions and Reagents}

The stock solution of 1000 $\mu \mathrm{g} / \mathrm{mL} \mathrm{Pb}$ was obtained from SCP Science AA Standards (Canada). Nitric acid $\left(\mathrm{HNO}_{3}, 65 \% \mathrm{v} / \mathrm{v}\right)$ and ammonium dihydrogen phosphate were purchased from Merck (Darm- stadt, Germany). All chemicals used were of analytical reagent grade unless otherwise specified. Ultrapure water using a Direct-Q8 system (Merck Millipore, Germany) with a resistivity of $18 \mathrm{M} \Omega \cdot \mathrm{cm}$ was used to prepare the solutions. Argon gas with a purity of $99.999 \%$ was purchased from a local supplier (Vasak Gaz, Ankara, Turkey). The reference materials used for validation of the method were High Purity Standards, Lead (High-Purity Standards, Inc., Charleston, SC, USA) and Seronorm ${ }^{\mathrm{TM}}$ Trace Elements Whole Blood L-2 (Sero AS, Billing-stad, Norway).

\section{Sample Collection}

This study involved 95 healthy, non-smoking, non-anemic pregnant women who have lived in Ankara,
Turkey, for more than 3 years. The maternal blood samples were collected at delivery by cesarean section or by spontaneous labor. Infant characteristics such as placental weight, birth weight, birth body length and head circumference were recorded. This study was ethically approved by the Research Ethics Committee of the Medical Faculty, Ankara University (Decision Number:33-730/2011). Each volunteer signed a consent form provided in accordance with the principles as established in The Declaration of Helsinki (World Medical Association, Declaration of Helsinki, 1964). The maternal blood samples were stored separately at $4^{\circ} \mathrm{C}$ in vacutainer blood collection tubes until the day of analysis.

TABLE I

GFAAS Instrumental Operating Parameters

$\begin{array}{ll}\text { Element, Matrix } & \text { Pb, Blood } \\ \text { Analytical Instrument } & \begin{array}{l}\text { Varian AA240Z } \\ \text { with Zeeman BC }\end{array} \\ \text { Concentration Unit } & \mu \mathrm{g} / \mathrm{L} \\ \text { Instrument Mode } & \text { Absorbance } \\ \text { Sampling } & \text { Auto-Mix } \\ \text { Total Injection Volume } & 20.0 \mu \mathrm{L} \\ \text { Matrix Modifier Volume } & 5.0 \mu \mathrm{L} \\ \text { Calibration Mode } & \text { Concentration } \\ \text { Measurement Mode } & \text { Peak Height } \\ \text { Replicates - Standard } & 3 \\ \text { Replicates - Sample } & 3 \\ \text { Expansion Factor } & 1.0 \\ \text { Wavelength } & 283.3 \mathrm{~nm} \\ \text { Slit Width } & 0.5 \mathrm{~nm} \\ \text { Gain } & 44 \% \\ \text { Current } & 10.0 \mathrm{~mA} \\ \text { Background Correction } & \mathrm{BC} \mathrm{on} \\ \text { Standard 1 } & 5.0 \mu \mathrm{g} / \mathrm{L} \\ \text { Standard 2 } & 10.0 \mu \mathrm{g} / \mathrm{L} \\ \text { Standard 3 } & 15.0 \mu \mathrm{g} / \mathrm{L} \\ \text { Standard 4 } & 20.0 \mu \mathrm{g} / \mathrm{L} \\ \text { Reslope Standard } & \text { Standard 2 } \\ \text { Recalibration Rate } & 50 \\ \text { Calibration Algorithm } & \text { Linear }\end{array}$




\section{Procedure}

In order to prepare the calibration standards at the concentrations of 5.0, 10.0, 15.0, and $20.0 \mu \mathrm{g} / \mathrm{L}$, a $1000 \mu \mathrm{g} / \mathrm{mL} \mathrm{Pb}$ stock solution was diluted with $4 \%$ (v/v) $\mathrm{HNO}_{3}$. All glassware was kept in $10.0 \%$ (v/v) nitric acid for at least one night prior to each experimental work. Before start of the analysis, the maternal blood samples were pretreated by addition of $5 \mathrm{~mL}$ of $65 \%$ (v/v) nitric acid, then a $1-\mathrm{mL}$ amount of maternal whole blood sample was taken into Teflon ${ }^{\circledR}$ tubes and placed into the microwave system (CEM Mars Xpress) for digestion of the samples. The microwave temperature program is listed in Table II. After digestion, all blood samples were diluted with ultra-pure water to 10-mL volume. Ammonium dihydrogen phosphate solution at the concentration of $5.0 \mathrm{mg} / \mathrm{mL}$ was used as the matrix modifier. A 5.0 $\mu \mathrm{L}$ amount of matrix modifier was automixed with the sample and 1\% (v/v) nitric acid.

\section{Optimization and Sample Treatment}

The major criteria for developing and optimizing this atomic spectrometric method required selection of the appropriate wavelength for the matrix and the concentration range in accordance with the elemental concentration in real blood samples, evaluation of the best furnace program and establishing the linearity $(14,15)$. The graphite furnace temperature program used for this study is listed in Table III.

The $\mathrm{Pb}$ determination was performed at the 283.3-nm line instead of the 217.0-nm line because it offers a better-signal-to noise ratio and lower background interferences. The method showed a linearity in the range of $0-100 \mu \mathrm{g} / \mathrm{L}$ for lead. The limit of linearity (LOL) is the concentration at which the calibration curve departs from the linearity and was found at $100 \mu \mathrm{g} / \mathrm{L}$ for this study. The calibration standards were prepared at the concentrations of 5.0, 10.0, 15.0, and 20.0 $\mu \mathrm{g} / \mathrm{L}$ due to the $\mathrm{Pb}$ concentration in real blood samples. The calibration graph for $\mathrm{Pb}$ showed good linearity in the concentration range examined (see Figure 1). The correlation

TABLE II

Temperature Program For Microwave Digestion

\begin{tabular}{ccclcc}
\hline $\begin{array}{c}\text { Maximum } \\
\text { Power }(W)\end{array}$ & $\begin{array}{c}\text { Power } \\
(\%)\end{array}$ & $\begin{array}{c}\text { Ramp } \\
\text { Time }(\mathrm{min})\end{array}$ & Pressure & $\begin{array}{c}\text { Temp. } \\
\left({ }^{\circ} \mathrm{C}\right)\end{array}$ & $\begin{array}{c}\text { Hold } \\
\text { Time }(\mathrm{min})\end{array}$ \\
\hline 1600 & 100 & $10: 00$ & Maximum & 210 & $10: 00$ \\
\hline
\end{tabular}

TABLE III

Graphite Furnace Temperature Program for Lead

\begin{tabular}{cccccccc}
\hline Step & $\begin{array}{c}\text { Temp. } \\
\left({ }^{\circ} \mathrm{C}\right)\end{array}$ & $\begin{array}{c}\text { Time } \\
(\mathrm{s})\end{array}$ & $\begin{array}{c}\text { Flow } \\
(\mathrm{L} / \mathrm{min})\end{array}$ & \multicolumn{2}{c}{$\begin{array}{c}\text { Signal } \\
\text { Collection }\end{array}$} & Reading \\
\hline 1 & 85 & 4.5 & 0.3 & $\times$ & No & $\times$ & No \\
2 & 95 & 36.9 & 0.3 & $\times$ & No & $\times$ & No \\
3 & 120 & 9.0 & 0.3 & $\times$ & No & $\times$ & No \\
4 & 400 & 4.5 & 0.3 & $\times$ & No & $\times$ & No \\
5 & 400 & 1.0 & 0.0 & $\sqrt{ }$ & Yes & $\times$ & No \\
6 & 2100 & 2 & 0.0 & $\sqrt{ }$ & Yes & $\sqrt{ }$ & Yes \\
7 & 2100 & 0.9 & 0.0 & $\sqrt{ }$ & Yes & $\sqrt{ }$ & Yes \\
8 & 2200 & 2.0 & 0.3 & $\times$ & No & $\times$ & No \\
\hline
\end{tabular}

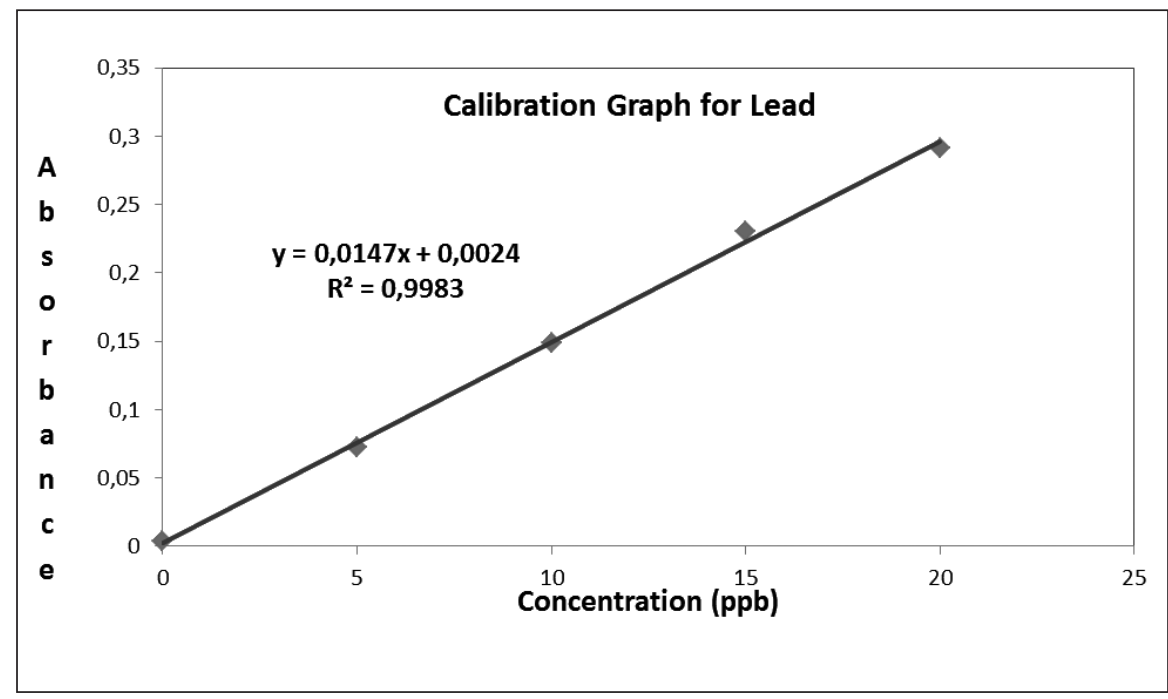

Fig. 1. Calibration graph of lead, performed by graphite furnace atomic absorption spectrometry (GFAAS), equipped with Zeeman effect background correction. 


\section{Method Validation}

To validate the method in terms of accuracy, precision and recovery, certified reference solutions of $100 \mu \mathrm{g} / \mathrm{L}$ amounts of High-Purity Standards Lead, and Seronorm ${ }^{\mathrm{TM}}$ Trace Elements Whole Blood L-2 were analyzed 10 times using triplicate measurements. The precision of the method is expressed as the relative standard deviation (\%RSD) of 10 independent analyses of the certified reference materials. Good agreement was obtained between the certified values and the measured $\mathrm{Pb}$ concentrations. The certified $\mathrm{Pb}$ content of the High Purity Standards Lead was $100 \pm 0.5 \mu \mathrm{g} / \mathrm{L}$, while the measured value was $102.40 \pm 1.80 \mu \mathrm{g} / \mathrm{L}$, with the successful percent recovery and relative standard deviation (RSD) of $102.4 \%$ and $1.75 \%$, respectively. Similarly, the certified $\mathrm{Pb}$ content of Seronorm ${ }^{\mathrm{TM}}$ Trace Elements Whole Blood L-2 was 336.0 \pm 18.0 $\mu \mathrm{g} / \mathrm{L}$, while the measured value was $324.36 \pm 22.0 \mu \mathrm{g} / \mathrm{L}$, with the successful percent recovery and relative standard deviation (RSD) of $96.50 \%$ and $6.80 \%$, respectively. The analytical results of the certified reference materials are also summarized in Table IV.

\section{Limit of Detection, Quantifica- tion and Linearity}

According to ICH guidelines (15, 16), the limit of detection (LOD) and the lowest limit of quantification (LOQ) are determined based on the standard deviation of the response and the slope of the calibration curve. They are calculated using $\mathrm{LOD}=3.3 \sigma / \mathrm{S}, \mathrm{LOQ}=10 \sigma / \mathrm{S}$, where $\sigma$ is the standard deviation of the response and $\mathrm{S}$ is the slope of the calibration curve. GFAAS method for lead analysis in maternal blood samples provided LOD and LOQ for lead equal to 0.34 $\mu \mathrm{g} / \mathrm{L}$ and $1.03 \mu \mathrm{g} / \mathrm{L}$, respectively. The dynamic range refers to the concentration intervals from LOQ to LOL, which for this study was found to be between 1.03 to 100.0 $\mu \mathrm{g} / \mathrm{L}$. The schematic diagram of the dynamic range study is shown in Figure 2.

\section{Statistical Analyses}

The findings of this study were statistically evaluated according to birth weight, birth body length, head circumference and placental weight. The Statistical Package for Social Sciences (SPSS), version 16.0 software for Windows ${ }^{\circledR}$, was used for the statistical analysis. All results were expressed as mean \pm standard deviation (SD) of the mean. Normality of data distribution was evaluated using the KolmogorovSmirnov test, and the correlations

\section{Atomic Apectroscopy \\ 1 Vol. 37(3), May/June 2016}

between the parameters were interpreted using the Pearson's test. The statistical analysis performed for maternal blood determination is summarized in Table V. The statistical significance was considered as $\mathrm{P}<0.05$.

\section{RESULTS AND DISCUSSION}

Lead is a cumulative toxic metal and exposure occurs from occupational and environmental sources mainly via inhalation and ingestion (17). Even at low levels, Pb can cause problems in the gastrointestinal, nervous, haematopoietic, and reproductive systems. Since early pregnancy is an important period in terms of fetal development,

TABLE IV

Analysis of Certified Reference Materials (CRMs)

\begin{tabular}{lccccc}
\hline CRMs & $\begin{array}{c}\text { Number } \\
\text { of Analyses } \\
(\mathrm{n})\end{array}$ & $\begin{array}{c}\text { Certified } \\
\text { Value } \\
(\mu \mathrm{g} / \mathrm{L})\end{array}$ & $\begin{array}{c}\text { Measured } \\
\text { Value } \\
(\mu \mathrm{g} / \mathrm{L})\end{array}$ & $\begin{array}{c}\text { Recov- } \\
\text { ery } \\
(\%)\end{array}$ & $\begin{array}{c}\text { RSD } \\
(\%)\end{array}$ \\
\hline $\begin{array}{l}\text { Seronorm } \\
\text { Whole Blood L-2 }\end{array}$ & 10 & $336.0 \pm 18.0$ & $324.36 \pm 22.0$ & 96.50 & 6.80 \\
$\begin{array}{l}\text { High Purity Standards, } \\
\text { Lead }\end{array}$ & 10 & $100.0 \pm 0.5$ & $102.40 \pm 1.80$ & 102.4 & 1.75 \\
\hline
\end{tabular}

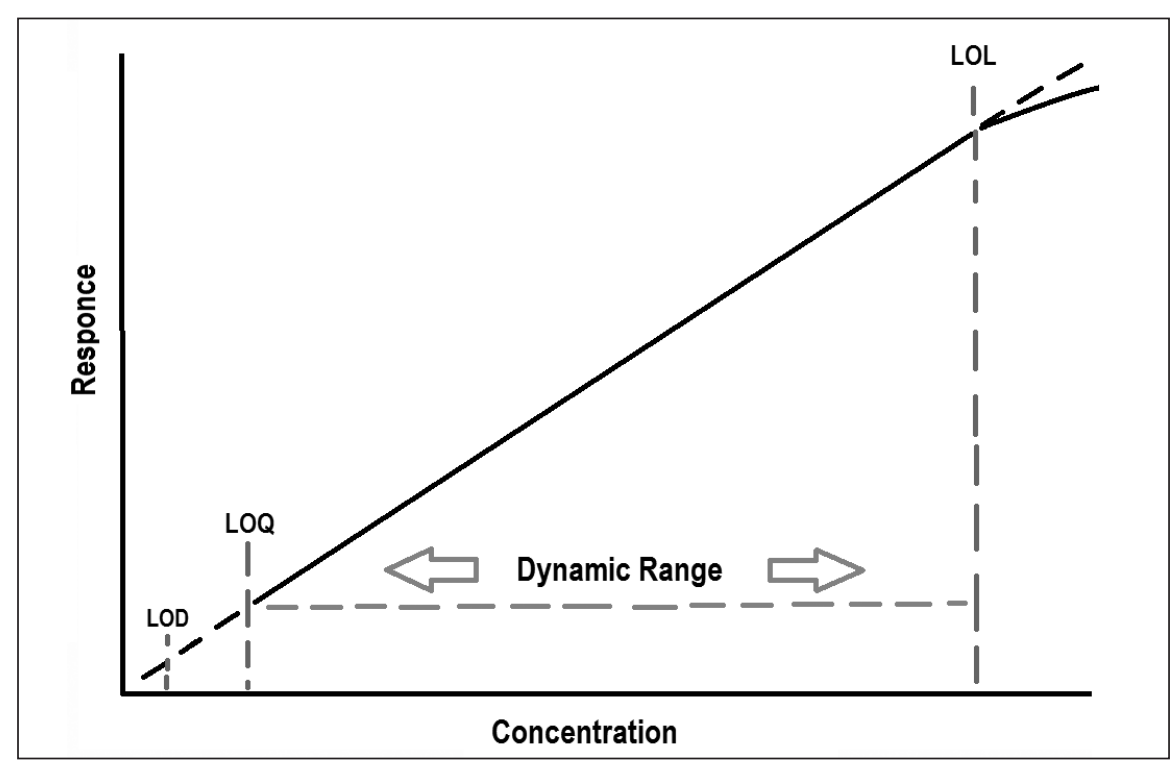

Fig. 2. Schematic diagram of dynamic range study: Dynamic range refers to concentration intervals from limit of quantification (LOQ) to limit of linearity (LOL). GFAAS method for lead analysis in maternal blood samples provided LOD, LOQ, and $\mathrm{LOL}$ equal to $0.34 \mu \mathrm{g} / \mathrm{L}, 1.03 \mu \mathrm{g} / \mathrm{L}$ and $100.0 \mu \mathrm{g} / \mathrm{L}$, respectively. 
avoidance of lead exposure by the mother is critical $(18,19)$. Recent studies discuss the dangers of prenatal exposure to the toxic metals such as lead, mercury, cadmium, and arsenic (20-30). Since lead crosses freely into the placenta, the fetus is exposed to lead in utero with the ratio of fetal:maternal blood lead ranging from 0.7 to 0.9 (31-33). Blood lead levels are now used as a common biomarker of lead exposure since it usually reflects current exposure to lead which has a biological half-life of about 30 days (34). For this reason, measuring maternal blood lead levels is an important biological monitoring program to be followed during pregnancy.

In the present study, infant characteristics such as placental weight, birth body weight, birth length, and head circumference were recorded in order to investigate whether or not there is any correlation between infant characteristics and maternal blood lead levels. The 95 mothers ranged in age from 18-41 years, with a mean age of $29.6 \pm 5.0$ years. All placentas were collected from the mothers who delivered neonates at term with normal birth weight (mean $3.32 \pm 0.46 \mathrm{~kg}$ ), birth body length (mean $49.75 \pm 1.97 \mathrm{~cm}$ ), head circumference (mean $35.26 \pm 1.12 \mathrm{~cm})$, and placental weight (mean 632.84 $153.0 \mathrm{~g}$ ). The maternal blood levels of this study were between 12.27 and $433.22 \mu \mathrm{g} / \mathrm{L}$, and the mean maternal blood lead levels were $41.80 \pm 33.97 \mu \mathrm{g} / \mathrm{L}$ (14), while the normal blood lead levels in adults and children were $200.0 \mu \mathrm{g} / \mathrm{L}$ and $50.0 \mu \mathrm{g} / \mathrm{L}$, respectively (35). The assessed lead levels in maternal blood samples are listed in Table VI.

\section{CONCLUSION}

Spectral analysis is considered to be one of the most exact of

TABLE V

Statistical Analysis Results of Pearson Correlation for Maternal Blood Lead Analysis

\begin{tabular}{|c|c|c|c|c|c|c|c|c|}
\hline & & \multicolumn{2}{|c|}{$\begin{array}{l}\text { Placental } \\
\text { Weight }\end{array}$} & \multicolumn{2}{|c|}{$\begin{array}{c}\text { Birth } \\
\text { Weight }\end{array}$} & \multicolumn{2}{|c|}{$\begin{array}{l}\text { Birth } \\
\text { Length }\end{array}$} & $\begin{array}{l}\text { Head Circum- } \\
\text { ference }\end{array}$ \\
\hline \multicolumn{9}{|c|}{ Maternal Blood Lead } \\
\hline \multicolumn{2}{|c|}{ Pearson Correlation } & \multicolumn{2}{|c|}{-0.021} & \multicolumn{2}{|c|}{-0.128} & \multicolumn{2}{|c|}{-0.081} & -0.106 \\
\hline \multicolumn{2}{|l|}{ Sig. (2-tailed) } & \multicolumn{2}{|c|}{0.840} & \multicolumn{2}{|c|}{0.216} & \multicolumn{2}{|c|}{0.434} & 0.308 \\
\hline \multicolumn{2}{|l|}{$\mathrm{N}$} & \multicolumn{2}{|r|}{95} & \multicolumn{2}{|r|}{95} & \multicolumn{2}{|r|}{95} & 95 \\
\hline \multicolumn{9}{|c|}{$\begin{array}{l}\text { a Correlation is significant at the } 0.01 \text { level (2-tailed). } \\
\text { b Correlation is significant at the } 0.05 \text { level (2-tailed). }\end{array}$} \\
\hline \multicolumn{9}{|c|}{$\begin{array}{c}\text { TABLE VI } \\
\text { Descriptive Statistics of Lead Levels in Maternal Blood Samples }\end{array}$} \\
\hline $\mathrm{N}=95$ & $\begin{array}{l}\text { Maternal } \\
\text { Blood } \\
\mathrm{Pb} \\
\text { (ppb) }\end{array}$ & $\begin{array}{l}\text { Age } \\
\text { (yrs) }\end{array}$ & $\begin{array}{r}\text { Place } \\
\text { Wei } \\
\text { (g) }\end{array}$ & & $\begin{array}{r}\text { Birth } \\
\text { Weigh } \\
(\mathrm{cm})\end{array}$ & & $\begin{array}{l}\text { Birth } \\
\text { Length } \\
(\mathrm{cm})\end{array}$ & $\begin{array}{l}\text { Head } \\
\text { Circum- } \\
\text { ference } \\
(\mathrm{cm})\end{array}$ \\
\hline Mean & 41.80 & 29.62 & 632. & & 3324.3 & & 49.75 & 35.26 \\
\hline Std. Deviation & 33.97 & 4.22 & 152. & & 461.8 & & 1.96 & 1.12 \\
\hline Minimum & 12.27 & 18 & & 0 & 230 & & 46 & 32.5 \\
\hline Maximum & 433.80 & 41 & 11 & & 450 & & 55 & 37.50 \\
\hline
\end{tabular}

methods for the determination of lead in blood samples. In this study, a graphite furnace atomic absorption spectrometry (GFAAS method, using Zeeman background correction, was developed for the determination of lead in maternal blood samples. The proposed method is relatively simple, rapid, sensitive and economical, and offers very good precision and accuracy. The method for blood lead analysis is competitive with other analytical approaches such as inductively coupled plasma mass spectroscopy (ICP-MS).

Apart from method validation and optimization for the determination of lead levels in maternal blood samples, this study also examined whether or not maternal blood lead levels have an effect on newborns. As a result of the statistical analyses, no statistically significant correlation was found between maternal blood lead levels and birth body weight $(r=-0.128, p=0.216)$, birth length $(\mathrm{r}=-0.081, \mathrm{p}=0.434)$, head circumferences $(\mathrm{r}=-0.106, \mathrm{p}=0.308)$, and placental weight $(\mathrm{r}=-0.021$, $\mathrm{p}=0.840$ ).

\section{ACKNOWLEDGMENT}

This work was financially supported by Ankara University Scientific Research Project Coordination Unit (BAP: Project No. 12H5150001).

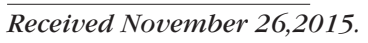

\section{REFERENCES}

1. A. Gürbay, M. Charehsaz, A. Eken, A. Sayal, G. Girgin, M. Yurdakök, S. Yigit, D. Demir Erol, G. Sahin, and A. Aydın, Biol. Trace Elem. Res. 149, 117-122 (2012).

2. H.S. D'Souza, G. Menezes, and T. Venkatesh, Indian. J. Clin. Biochem. 18, 154-160 (2003).

3. D. Tekin, Z. Kayaalt1, and T. Söylemezoglu, Int. Arch. Occup. Environ. Health 85, 631-637 (2012). 
4. IARC (International Agency for Research on Cancer) Classified by the IARC Monographs, Volumes 1-102 (2012).

5. S. Tong, Y. E. von Schirnding, and T. Prapamontol, Bull. World Health Organ. 78 (9), 1070 (2000)

6. J.G. Dorea, Br. J. Nutr. 92, 21 (2004)

7. R.A. Goyer, Environ. Health Respects. 89, 101 (1990).

8. R.A. Goyer, Annual. Rev. Nutr. 17, 37 (1997).

9. R.M. Molina, S. Phattanarudee, J. Kim, K. Thompson, M. WesslingResnick, T.J. Maher, and J.D. Brain, Neurotoxicol. 32, 413 (2011).

10. I. Al-Saleh, N. Shinwari, A. Mashhour, D. Mohamed-Gel and A. Rabah, Int. J. Hyg. Environ. Health 214, 79 (2011).

11. P.A. Baghurst. E.F. Robertson, R.K. Oldfield, B.M. King, A.J. Mc Micheal, G.V. Vimpani and N.R. Wigg, Environ. Health Perspect. 90, 315 (1991).

12. E.W. Harville, I. Hertz-Picciotto, M. Schramm, M. Watt-Morse, K. Chantala, J. Osterloh, P.J. Parsons and W. Rogan, Occup. Environ. Med. 62, 263 (2005.)

13. B.L. Gulson, K.R. Mahaffey, C.W. Jameson, N. Patison, A.J. Law, K.J. Mizon, M.J Korsch and D. Pederson, Environ. Health. Perspect. 107, 257 (1999).

14. Z. Kayaaltı, B. Yüksel, D. KayaAkyüzlü, D. Tekin, and T. Söylemezoglu, Toxicol. Lett., Supplement, 238(2), 366 (2015).

15. B. Yüksel, Z. Kayaaltı, T. Söylemezoglu, V.A. Türksoy and E. Tutkun, At. Spectrosc. 36(4), 171 (2015).

16. International Conference on Harmonization $(\mathrm{ICH})$ of Technical Requirements for the Registration of Pharmaceuticals for Human Use, Validation of Analytical Procedures: Methodology (ICBQ2B) (1996).

17. Z. Kayaaltı, D. Kaya-Akyüzlü and T. Söylemezoglu Environ. Res. 137, 8 (2015).

18. P.D. Gluckman, M.A. Hanson, C. Cooper and K.L. Thornburg, N. Engl J. Med. 359, 61( 2008).
19. S. Selevan, C. Kimmel and P. Mendola, Environ. Health Perspect. 108(3), 451 (2000)

20. P. Drouillet-Pinard, G. Huel, R. Slama, A. Forhan, J. Sahuquillo, V. Goua, O. Thiébaugeorges, B. Foliguet, G. Magnin, M. Kaminski, S. Cordier, M.A. Charles, Br.J.Nutr.104, 1096 (2010).

21. C. Gundacker, S. Fröhlich, K. GrafRohrmeister, B. Eibenberger, V. Jessenig, and D. Gicic, Sci. Total Environ. 408, 5744 (2010).

22. M. Kippler, F. Tofail, R. Gardner, A. Rahman, J. Hamadani and M. Bottai, Environ. Health Perspect. 284, 284 (2012).

23. C.M. Lin, P. Doyle, D. Wang, Y.H. Hwang and P.C. Chen, Occup. Environ. Med. 68, 641(2011).

24. M. Menai, B. Heude, R. Slama, A. Forhan, J. Sahuquillo, M.A. Charles, and C. Yazbeck, Reprod. Toxicol. 34, 622 (2012).

25. L.M. Schell, M. Denham, A.D. Stark, P.J. Parsons, and E.E. Schulte, Am. J. Hum. Biol. 21, 180 (2009)

26. X. Xie, G. Ding, C. Cui, L. Chen, Y. Gao, Y. Zhou, R. Shi and Y. Tian, Environ. Pollut. 175, 30 (2013)

27. M. Zhu, E.F. Fitzgerald, K.H. Gelberg, S. Lin, and C.M. Druschel, Environ. Health Perspect. 118, 1471 (2010).

28. D.B. Barr, A. Bishop, L.L. Needham, Reprod. Toxicol. 23, 260 (2007).

29. C.D. Klaasen and J.B. Watkins III, Casarett and Doull's Essentials of Toxicology, 2nd ed., McGraw-Hill Medical, New York, USA (2010).

30. L.L. Needham, P. Grandjean, B. Heinzow, P.J. ,Jørgensen, F. Nielsen, and D.J. Patterson, Environ. Sci. Technol. 45, 1121 (2011).

31. J.H. Amaral, V.B. Rezende, S.M. Quintana, R.F. Gerlach, Jr. F. Barbosa, J.E. Tanus-Santos, Basic Clin. Pharmacol. Toxicol. 107, 971 (2010).

32. C.V. Rudge, H.B. Rollin, C.M. Nogueira, Y. Thomassen, M.C. Rudge, and J.O. Odland, J. Environ. Monitor 11, 1322 (2009).
33. L.M. Schell, M. Denham, A.D Stark, M. Gomez, J. Ravenscroft, P.J. Parsons, A. Aydermir and R. Samelson, Environ. Health Perspect. 111, 195 (2003)

34. F. Barbosa, Jr., J.E. Tanus-Santos, R.F. Gerlach, and P.J. Parsons, Environ. Health Perspect. 113, 1669 (2005).

35. Agency for Toxic Substances and Disease Registry (ATSDR), Toxicological profile for lead, Atlanta, GA: US Public Health Service (2007). 